\title{
WILD ONION (Asphodelus tenuifolius) COMPETITION IN RAINFED Chickpea-Chickpea Cropping System ${ }^{1}$
}

\author{
Competição da Cebola Selvagem (Asphodelus tenuifolius) em Sistema de Cultivo de Grão-de- \\ Bico em Sequeiro
}

\author{
SIBTAIN, M. ${ }^{2}$, TANVEER, A. ${ }^{2}$, JAVAID, M.M. ${ }^{3}$, and ALI, H.H. ${ }^{4}$
}

\begin{abstract}
Chickpea yield potential is limited by weed competition in typical chickpea growing areas of Pakistan where zero tillage crop grown on moisture conserved from rains received during the months of September and August. The objective of this work was to evaluate the growth and yield characteristics of chickpea grown in coexistence with increasing densities of wild onion (Asphodelus tenuifolius). The experiment was comprised of six density levels viz. zero, 20, 40, 80, 160 and 320 plants $\mathrm{m}^{-2}$ of $A$. tenuifolius. A decrease in chickpea primary and secondary branches per plant, pods per plant, seeds per pod, 100-seed weight and seed yield was observed due to more accumulation of dry matter per increasing densities of $A$. tenuifolius. The increase in $A$. tenuifolius density accelerated chickpea yield losses and reached the maximum values of $28,35,42,50,58$ and $96 \%$ at $20,40,80,160$ and 320 A. tenuifolius plants $\mathrm{m}^{-2}$, respectively. The yield loss estimation model showed that chickpea losses with infinite A. tenuifolius density were $60 \%$. Yield reduction could be predicted by $2.52 \%$ with increase of one $A$. tenuifolius plant $\mathrm{m}^{-2}$. It is concluded that $A$. tenuifolius has a strong influence on chickpea seed yield and showed a linear response at the range of densities studied.
\end{abstract}

Keywords: Cicer arietinum, weed density, yield components, grain yield.

RESUMO - Grão de bico potencial de produção é limitada pela competição com plantas daninhas em áreas de cultivo de sementes do grão típico do Paquistão, onde o plantio direto de culturas cultivadas em umidade conservada de chuvas de monção de verão. O objetivo deste trabalho foi avaliar o crescimento ea produção de grão de bico personagens cultivadas em convivência com o aumento da densidade de cebola Silvestre (Asphodelus tenuifolius). O experimento foi composto de seis niveis de densidade viz. de zero, 20, 40, 80, 160 e 320 plantas $\mathrm{m}^{-2}$ de A. tenuifolius. Diminuição no primário de grão de bico e ramos secundários por planta, vagens por planta, de sementes por vagem, peso e rendimento de sementes de 100 sementes foi observada devido a uma maior acumulação de matéria seca por aumento da densidade de A. tenuifolius. Aumento da densidade de A. tenuifolius acelera as perdas de rendimento de grão de bico e atingindo os valores máximos de 28, 35, 42, 50, 58 e 96\% em 20, 40, 80, 160 e 320 A. tenuifolius plantas $\mathrm{m}^{-2}$, respectivamente. Modelo de estimativa de perda de rendimento mostrou que as perdas de grão de bico com infinita densidade A. tenuifolius eram $60 \%$. A redução no rendimento pode ser previsto por 2,52\% com um aumento de $\boldsymbol{A}$. tenuifolius $\mathrm{m}^{-2}$. Conclui-se que $\boldsymbol{A}$. tenuifolius tem uma forte influência sobre o rendimento de sementes de grão de bico, mostrando uma resposta linear na faixa de densidades estudadas.

Palavras-chave: Cicer arietinum, densidade de plantas daninhas, componentes de produção, produtividade de grãos.

Recebido para publicação em 30.8.2014 e aprovado em 16.12.2014.

Department of Agronomy, University of Agriculture Faisalabad, 38040, Faisalabad, Pakistan, <drasiftanveeruaf@hotmail.com>; ${ }^{3}$ Department of Agronomy, Muhammad Nawaz Shareef University of Agriculture, Multan, Pakistan. ${ }^{4}$ Department of Agronomy, University College of Agriculture and Environmental Sciences, The Islamia University of Bahawalpur, Pakistan. 


\section{INTRODUCTION}

Chickpea (Cicer arietinun) is a pulse grown throughout the world, mainly in dry areas. In Pakistan, it is an important winter crop in rainfed areas where the crop is sown on soil moisture preserved from the summer monsoon (July-September). Yield losses of 244-80\% have been reported in chickpea due to weeds (Tiwari et al., 2001). Losses due to weeds depend upon the types and density of weeds, time of weed seed germination, duration of weed infestation, space available for growth, environmental factors and management practices which affect weed seeds germination and subsequent growth of seedlings. A common belief that has been supported by experiments is that there are more yield losses in chickpea as weed density increased (Tanveer et al., 1998; Whish et al., 2002).

Weed threshold density level is the point in weed infestation (number or weight) at which crop yield begins to reduce. To avoid or compensate yield losses, estimation of economic weed population (density) and its management by an effective method are very important in crop production (Deines et al., 2004). In weed management, the importance of weed threshold level is in open sight, because it is very helpful for farmers that use herbicides (Portugal \& Vidal, 2009). Weed threshold density levels, reproduction and growth behaviors are different for different weed species (Onofri \& Tei, 2006). Estimation of weed threshold level offers a deep insight for decisions about an appropriate and effective weed control method for a certain weed population in order to prevent economic losses (Fleck et al., 2002; Knezevic et al., 2002). Wild onion is a very harmful and noxious weed in chickpea, wheat, mustard, linseed and lentil in Pakistan and India (Nasir \& Sultan, 2004) due to its high competitive ability, greater production of seeds and reproduction potential. It is found in almost 17 countries of the world (Holm et al., 1977). Although competitive effects of $A$. tenuifolius have been studied in wheat, lentil and mustard, no research has been conducted on its competitive effects on chickpea under rainfed chickpea-chickpea cropping system (Mishra et al., 2006). The main objectives of this study were to study the competitive effect of $A$. tenuifolius and to investigate the economic threshold level of A. tenuifolius in rainfed chickpea.

\section{MATERIALS AND METHODS}

Field experiments were conducted during chickpea growing season in 2008-09 and 200910 on sandy soil with $\mathrm{pH}$ of 8.2 in Bhakkar $\left(31^{\circ} \mathrm{N}\right.$ and $\left.71^{\circ} \mathrm{E}\right)$, Pakistan. The experimental area has a chickpea-chickpea cropping system. Chickpea cultivar "Bittal-98" was sown in rows spaced $30 \mathrm{~cm}$ apart on October 25, 2008 and on October 22, 2009 with a tractor mounted drill using a seed rate of $60 \mathrm{~kg} \mathrm{ha}^{-1}$. The experiment was comprised of $0,20,40$, 80, 160 and 320 A. tenuifolius plants $\mathrm{m}^{-2}$. No land preparation was done before chickpea was sown in both years of experimentation, and the crop was sown on residual moisture of JulyAugust rainfall. Crop rotation of chickpeachickpea is common in the area covered by our study. Neither irrigation nor NPK fertilizer was applied to the crop. The crop was sown in the field where there was heavy infestation of $A$. tenuifolius in the previous year. All weeds other than A. tenuifolius (e.g Chenopodium album, Convolvolus arvensis and Euphorbia dracunculoides) were pulled out when they emerged. However, all weeds in control, including A. tenuifolius, were pulled out manually soon after their emergence (weed free plots). Asphodelus tenuifolius plants more than required were removed manually after every three days to maintain the required density in both years.

\section{Statistical analysis}

The experiment was arranged in a randomized complete block design (RCBD) with four replications. Data of both years were different so they could not be combined. Data underwent analysis of variance (ANOVA) with PROC GLM in SAS 9.0 (2002), and means were separated with Fisher's protected LSD at $\mathrm{P} \leq 0.05$ level of probability (Steel et al., 1997).

A non-linear rectangular hyperbolic regression model (Cousens, 1985) was fitted to the chickpea yield and $A$. tenuifolius density data to analyze the relationship between chickpea yield (Y) and A. tenuifolius density (d). The model equation is expressed below. 


$$
Y=Y_{w f}\left[1-\frac{i \times d}{100 \times \frac{i \times d}{A}}\right]
$$

where $Y$ is the observed wheat yield $\left(\mathrm{kg} \mathrm{ha}^{-1}\right)$ in a particular weed density, $Y_{w f}$ is the weed free crop yield, $i$ is the percent of yield loss per unit of weed density $(d)$ as $d \rightarrow 0, d$ is weed density, $A$ is the asymptotic value of the maximum yield loss (\%), as $d \rightarrow \infty$. Parameter estimates were determined for the model using the nonlinear regression technique.

\section{RESULTS AND DISCUSSION}

Varying densities of $A$. tenuifolius had a significant effect on its dry weight $\left(\mathrm{g} \mathrm{m}^{-2}\right)$ (Table 1). Data showed that A. tenuifolius dry weight was progressively increased as A. tenuifolius densities increased from 20 to $320 \mathrm{~m}^{-2}$. Minimum $\left(25.48 \mathrm{~g} \mathrm{~m}^{-2}\right)$ and maximum (188.97 $\mathrm{g} \mathrm{m}^{-2}$ ) dry weight of $A$. tenuifolius was recorded at its lowest $\left(20\right.$ plants $\left.\mathrm{m}^{-2}\right)$ and highest (320 plants $\mathrm{m}^{-2}$ ) density level, respectively, during 2008-09 (Table 1). In 200910 , the trend of $A$. tenuifolius dry weight was similar. Linear, quadratic and cubic responses of $A$. tenuifolius densities for dry weight were significant for both years (Table 1). Our data showed that with increasing $A$. tenuifolius densities, its dry weight $\left(\mathrm{g} \mathrm{m}^{-2}\right)$ was increased significantly. This could be attributed to an increase in fresh weight; thus, our findings are comparable with those of Mishra et al. (2006). Those authors reported the highest dry weight of $A$. tenuifolius per unit area at its highest density. Similarly, Silva et al. (2008) and Rizzardi et al. (2004) recorded the highest dry matter production of different densities of E. heterophylla, Digitaria horizontalis, Cyperus rotundus and Ipomoea nil when competing with soybean.

Varying densities of $A$. tenuifolius had a significant effect on its height (Table 1). A progressive increase in $A$. tenuifolius height occured by increasing its density. The tallest A. tenuifolius plants $(61 \mathrm{~cm})$ were observed at its density level of 320 plants $\mathrm{m}^{-2}$ and the shortest $A$. tenuifolius plants were noted at its density level of 20 plants $\mathrm{m}^{-2}(54.25 \mathrm{~cm})$. However, maximum height of $A$. tenuifolius was similar in plots where 80, 160 and 320 A. tenuifolius plants $\mathrm{m}^{-2}$ were maintained during 2008-09 (Table 1). Nevertheless, in 2009-10, the tallest $(70 \mathrm{~cm})$ A. tenuifolius plants were measured at a density level of 320 plants $\mathrm{m}^{-2}$, which was similar $(67 \mathrm{~cm})$ to that of 160 A. tenuifolius plants $\mathrm{m}^{-2}$ only. Linear, quadratic and cubic responses for A. tenuifolius height were significant in 200809 and in 2009-10 (Table 1). Our results demonstrated that the tallest $A$. tenuifolius plants in plots with maximum density $\mathrm{m}^{-2}$ (320) were due to severe competition for light and, as a result, $A$. tenuifolius attained more height

Table 1 - Effect of A. tenuifolius densities on its different attributes

\begin{tabular}{|c|c|c|c|c|c|c|c|c|c|c|}
\hline \multirow{2}{*}{$\begin{array}{l}\text { A. tenuifolius } \\
\text { density }\left(\mathrm{m}^{-2}\right)\end{array}$} & \multicolumn{2}{|c|}{ Dry weight $\left(\mathrm{g} \mathrm{m}^{-2}\right)$} & \multicolumn{2}{|c|}{ Height $(\mathrm{cm})$} & \multicolumn{2}{|c|}{ Shoots per plant } & \multicolumn{2}{|c|}{ Capsules per plant } & \multicolumn{2}{|c|}{$\begin{array}{l}\text { Seed weight per } \\
\text { plant }(\mathrm{g})\end{array}$} \\
\hline & 2008-09 & 2009-10 & $2008-09$ & $2009-10$ & 2008-09 & $2009-10$ & 2008-09 & $2009-10$ & 2008-09 & $2009-10$ \\
\hline 0 & $0.00 \mathrm{f}$ & $0.00 \mathrm{f}$ & $0.00 \mathrm{c}$ & $0.00 \mathrm{~d}$ & $0.00 \mathrm{c}$ & $0.00 \mathrm{~d}$ & $0.00 \mathrm{c}$ & $0.00 \mathrm{~d}$ & $0.00 \mathrm{~d}$ & $0.00 \mathrm{~d}$ \\
\hline 20 & $25.48 \mathrm{e}$ & $19.83 \mathrm{e}$ & $54.25 \mathrm{~b}$ & $59.00 \mathrm{c}$ & $5.00 \mathrm{a}$ & $5.75 \mathrm{a}$ & $380.00 \mathrm{a}$ & $385.00 \mathrm{a}$ & $14.75 \mathrm{a}$ & $15.00 \mathrm{a}$ \\
\hline 40 & $48.08 \mathrm{~d}$ & $52.07 \mathrm{~d}$ & $54.50 \mathrm{~b}$ & $59.00 \mathrm{c}$ & $4.75 \mathrm{ab}$ & $5.75 \mathrm{a}$ & $367.50 \mathrm{a}$ & $370.00 \mathrm{ab}$ & $13.50 \mathrm{a}$ & $13.50 \mathrm{~b}$ \\
\hline 80 & $76.44 \mathrm{c}$ & $75.96 \mathrm{c}$ & $59.25 \mathrm{a}$ & $64.00 \mathrm{~b}$ & $4.75 \mathrm{ab}$ & $5.00 \mathrm{~b}$ & $359.75 \mathrm{a}$ & $358.50 \mathrm{~b}$ & $13.25 \mathrm{ab}$ & $13.00 \mathrm{~b}$ \\
\hline 160 & $118.18 \mathrm{~b}$ & $126.76 \mathrm{~b}$ & $59.75 \mathrm{a}$ & $67.00 \mathrm{ab}$ & $4.50 \mathrm{ab}$ & $4.50 \mathrm{~b}$ & $317.50 \mathrm{~b}$ & $323.00 \mathrm{c}$ & $11.50 \mathrm{bc}$ & $10.00 \mathrm{c}$ \\
\hline 320 & $188.97 \mathrm{a}$ & $201.00 \mathrm{a}$ & $61.00 \mathrm{a}$ & $70.00 \mathrm{a}$ & $4.00 \mathrm{~b}$ & $3.25 \mathrm{c}$ & $317.00 \mathrm{~b}$ & $316.00 \mathrm{c}$ & $10.25 \mathrm{c}$ & $9.50 \mathrm{c}$ \\
\hline LSD & 14.67 & 10.64 & 3.37 & 3.94 & 0.94 & 0.61 & 38.66 & 20.50 & 1.87 & 1.25 \\
\hline \multicolumn{11}{|c|}{ Trend comparison } \\
\hline Linear & $* *$ & $* *$ & $* *$ & $* *$ & $* *$ & $* *$ & $* *$ & $* *$ & $* *$ & $* *$ \\
\hline Quadratic & $* *$ & $* *$ & $* *$ & $* *$ & $* *$ & $* *$ & $* *$ & $* *$ & $* *$ & $* *$ \\
\hline Cubic & $*$ & $* *$ & $* *$ & $* *$ & $* *$ & $* *$ & $* *$ & $* *$ & $* *$ & $* *$ \\
\hline
\end{tabular}

Means not sharing same letter in a column were significantly different at $5 \%$ probability level. ${ }^{* *}$ Indicates significance at $\mathrm{P} \leq 0.01$ level of probability. 
as compared with that of the lowest density $\mathrm{m}^{-2}$. The results dissimilar with our findings were described by Khan et al. (2006) and Oad et al. (2007). They recorded a decrease in wheat height with increasing weed densities. Normally, weed/crop height is decreased with an increase in population because inter or intra-specific competition is increased with an increase in population.

The effect of different A. tenuifolius densities on shoot number per plant was shown in Table 1. A. tenuifolius shoots per plant were decreased with an increase in its density. A minimum number of 4.00 A. tenuifolius shoots was observed in plots with 320 A. tenuifolius $\mathrm{m}^{-2}$, whereas at the lowest density level of $A$. tenuifolius (20 plants $\mathrm{m}^{-2}$ ), the maximum number of shoots was 5.00 per plant in 2008-09. A similar trend in maximum and minimum number of $A$. tenuifolius shoots per plant was observed in 2009-10 (Table 1). Trend comparisons for $A$. tenuifolius shoots were significant in linear, quadratic and cubic responses in both years (Table 1). Our findings revealed that a decrease in the number of shoots of $A$. tenuifolius with an increase in its density was due to increased intraspecific and interspecific competition for resources like water, nutrients and light, etc. At highest densities, individual share of weed plants in utilizing resources is decreased markedly, which negatively affect their vegetative and reproductive growth. Similarly, Mishra et al. (2006) found a decrease in leaf and inflorescence numbers of $A$. tenuifolius competing with wheat crop plants.

Table 1 showed that varying $A$. tenuifolius densities had a negative effect on its number of capsules per plant. Increasing density of Asphodelus tenuifolius from 20 to $80 \mathrm{~m}^{-2}$ produced 380.00 to 359.75 capsules per plant in 2008-09. In contrast, in 2009-10, maximum (385) A tenuifolius capsules were recorded at density level of 20 plants $\mathrm{m}^{-2}$ and were statistically similar with plots (367 capsules) having $40 \mathrm{~A}$. tenuifolius $\mathrm{m}^{-2}$. Minimum A. tenuifolius capsules per plant (317) were counted at 320 A. tenuifolius $\mathrm{m}^{-2}$. Linear, quadratic and cubic responses for $A$. tenuifolius capsules per plant were significant in both years (Table 1). Data obtained in the study illustrated that an increase in A. tenuifolius densities from 20 to 320 plants $\mathrm{m}^{-2}$ caused a progressive decline in its number of capsules. It could be due to increased competition for resources (light, moisture and nutrients) with increasing $A$. tenuifolius density $\mathrm{m}^{-2}$ which resulted in fewer $A$. tenuifolius shoots per plant. This ultimately decreased its inflorescences and produced fewer capsules per plant. Similarly to our findings, Sester et al. (2004) reported a decrease in flowers of beet weed when its density was increased.

Data showed that variation of $A$. tenuifolius densities had a significant effect on its seed weight per plant (Table 1). In 2008-09, maximum seed weight of $A$. tenuifolius $(14.75 \mathrm{~g})$ was produced at $20 \mathrm{~A}$. tenuifolius $\mathrm{m}^{-2}$, which was statistically similar to the plots where 40 and 80 plants of $A$. tenuifolius were maintained (Table 1). Similarly, in 2009-10, maximum seed weight of $A$. tenuifolius per plant was $15 \mathrm{~g}$ at $A$. tenuifolius density of $20 \mathrm{~m}^{-2}$, followed by those of 40 and 80 plants of A. tenuifolius $\mathrm{m}^{-2}$ (Table 1 ). The lowest seed weight (10.25 and 9.50 g per plant) was observed with 320 plants of A. tenuifolius $\mathrm{m}^{-2}$ in 2008-09 and 2009-10, respectively. Linear, quadratic and cubic trend comparisons for A. tenuifolius seed weight were significant in both years (Table 1 ). As $A$. tenuifolius shoots and capsules per plant were higher at 20, 40 and $80 \mathrm{~A}$. tenuifolius plants $\mathrm{m}^{-2}$, ultimately seed weight of these plants was higher. Our results are comparabe with those of (Aziz et al., 2009; Abbas et al., 2010), who revealed more seed weight of Galium aparine and Emex australis at their lowest densities in wheat. Similarly, Sester et al. (2004) also achieved a smaller number of beet weed seeds (per plant) when its density was decreased.

Data showed the evidence that chickpea primary branches per plant were significantly affected by varying $A$. tenuifolius density levels $\left(\mathrm{m}^{-2}\right)$. Maximum chickpea primary branches per plant (4.75 to 5.25 ) were recorded in $A$. tenuifolius free plots and minimum ones (2.25 to 2.50) were observed with 320 A. tenuifolius $\mathrm{m}^{-2}$ in 2008-09 and 2009-10 (Table 2). However, in 2008-09, chickpea plots where $A$. tenuifolius density increased from 0 to 40 plants $\mathrm{m}^{-2}$ did not affect primary branches of chickpea (per plant). Above this density 
Table 2 - Effect of A. tenuifolius densities on yield and yield components of chickpea

\begin{tabular}{|c|c|c|c|c|c|c|c|c|c|c|c|c|}
\hline \multirow{2}{*}{$\begin{array}{l}\text { A. tenuifolius } \\
\text { density }\left(\mathrm{m}^{-2}\right)\end{array}$} & \multicolumn{2}{|c|}{$\begin{array}{l}\text { Primary branches } \\
\text { per plant. }\end{array}$} & \multicolumn{2}{|c|}{$\begin{array}{c}\text { Secondary } \\
\text { branches per plant }\end{array}$} & \multicolumn{2}{|c|}{ Pods per plant } & \multicolumn{2}{|c|}{ Seeds per pod } & \multicolumn{2}{|c|}{$\begin{array}{c}\text { 100-seed weight } \\
(\mathrm{g})\end{array}$} & \multicolumn{2}{|c|}{$\begin{array}{l}\text { Seed yield } \\
\left(\mathrm{kg} \mathrm{ha}^{-1}\right)\end{array}$} \\
\hline & 2008-09 & 2009-10 & 2008-09 & 2009-10 & 2008-09 & 2008-09 & $2009-10$ & 2009-10 & 2008-09 & 2009-10 & 2008-09 & $2009-10$ \\
\hline 0 & $4.75 \mathrm{a}$ & $5.25 \mathrm{a}$ & $20.00 \mathrm{a}$ & $19.00 \mathrm{a}$ & $63.25 \mathrm{a}$ & $66.00 \mathrm{a}$ & $2.25 \mathrm{a}$ & $2.25 \mathrm{a}$ & $21.00 \mathrm{a}$ & $21.15 \mathrm{a}$ & $2467 \mathrm{a}$ & $2579 a$ \\
\hline 20 & $4.50 \mathrm{a}$ & $4.75 \mathrm{a}$ & $18.00 \mathrm{a}$ & $16.00 \mathrm{~b}$ & $58.00 \mathrm{~b}$ & $59.50 \mathrm{~b}$ & $2.00 \mathrm{ab}$ & $2.00 \mathrm{ab}$ & $20.74 \mathrm{a}$ & $20.61 \mathrm{ab}$ & $1879 \mathrm{~b}$ & $1851 \mathrm{~b}$ \\
\hline 40 & $4.00 \mathrm{ab}$ & $4.00 \mathrm{~b}$ & $14.25 \mathrm{~b}$ & $14.00 \mathrm{bc}$ & $52.00 \mathrm{c}$ & $53.00 \mathrm{c}$ & $2.00 \mathrm{ab}$ & $2.00 \mathrm{ab}$ & $20.40 \mathrm{ab}$ & $20.25 \mathrm{ab}$ & $1638 \mathrm{c}$ & $1676 \mathrm{c}$ \\
\hline 80 & $3.50 \mathrm{~b}$ & $3.75 \mathrm{~b}$ & $13.25 \mathrm{~b}$ & $12.75 \mathrm{c}$ & $47.50 \mathrm{~d}$ & $49.00 \mathrm{~d}$ & $1.50 \mathrm{~b}$ & $1.50 \mathrm{~b}$ & $20.35 \mathrm{ab}$ & $20.25 \mathrm{ab}$ & $1491 \mathrm{~d}$ & $1480 \mathrm{~d}$ \\
\hline 160 & $3.50 \mathrm{~b}$ & $3.75 \mathrm{~b}$ & $12.25 \mathrm{~b}$ & $12.00 \mathrm{c}$ & $47.00 \mathrm{~d}$ & $47.00 \mathrm{~d}$ & $1.50 \mathrm{~b}$ & $1.50 \mathrm{~b}$ & $19.90 \mathrm{~b}$ & $19.99 \mathrm{~b}$ & $1340 \mathrm{e}$ & $1280 \mathrm{e}$ \\
\hline 320 & $2.25 \mathrm{c}$ & $2.50 \mathrm{c}$ & $6.25 \mathrm{c}$ & $7.00 \mathrm{~d}$ & $30.00 \mathrm{e}$ & $33.00 \mathrm{e}$ & $1.50 \mathrm{~b}$ & $1.50 \mathrm{~b}$ & $19.89 \mathrm{~b}$ & $19.70 \mathrm{~b}$ & $1118 \mathrm{f}$ & $1068 \mathrm{f}$ \\
\hline LSD & 0.93 & 0.75 & 2.22 & 2.66 & 3.85 & 3.17 & 0.71 & 0.67 & 0.69 & 1.06 & 115 & 86 \\
\hline \multicolumn{13}{|c|}{ Trend comparison } \\
\hline Linear & $* *$ & $* *$ & $* *$ & $* *$ & $* *$ & $* *$ & $* *$ & $* *$ & $* *$ & $* *$ & $* *$ & $* *$ \\
\hline Quadratic & NS & NS & NS & NS & ** & NS & NS & NS & NS & NS & $* *$ & ** \\
\hline Cubic & NS & NS & $*$ & $*$ & ** & $* *$ & NS & NS & NS & NS & ** & ** \\
\hline
\end{tabular}

Means not sharing same letter in a column were significantly different at $5 \%$ probability level. ${ }^{\text {Ns }}$ and ${ }^{* *}$ indicate non-significant and significant at $\mathrm{P} \leq 0.01$ level of probability, respectively.

level, chickpea primary branches decreased with an increase in $A$. tenuifolius plants $\mathrm{m}^{-2}$, and minimum chickpea primary branches were observed at 320 A. tenuifolius plants $\mathrm{m}^{-2}$ in 2008-09. In contrast, a significant reduction in primary branches per plant of chickpea was started from plots where 40 plants of A. tenuifolius were maintained in 2009-10 (Table 2). The trend comparison shown in Table 2 showed a significant linear response and non-significant quadratic and cubic responses in both years of study. Generally, with increasing $A$. tenuifolius densities $\mathrm{m}^{-2}$, a decrease in primary branches of chickpea per plant was noted. This progressive reduction in primary branches is due to limitation of resource availability i.e., at higher A. tenuifolius densities, weed-crop competition was severe. Fast et al. (2009) reported a reduction in productive tillers of wheat with increasing weed densities.

The effect of different $A$. tenuifolius densities on secondary branches of chickpea per plant is shown in Table 2. Chickpea secondary branches were significantly decreased with an increase in $A$. tenuifolius densities $\left(\mathrm{m}^{-2}\right)$. In 2008-09, maximum chickpea secondary branches (18-20 per plant) were produced at 0 or $20 \mathrm{~A}$. tenuifolius $\mathrm{m}^{-2}$. At 40 A. tenuifolius $\mathrm{m}^{-2}$, chickpea secondary branches significantly decreased when compared with 0 or 20 plants of $A$. tenuifolius $\mathrm{m}^{-2}$ and after this level, there was no significant decrease in chickpea secondary branches with an increase in $A$. tenuifolius density upto 160 plants of $A$. tenuifolius $\mathrm{m}^{-2}$. Minimum chickpea secondary branches were recorded at 320 plants of $A$. tenuifolius $\mathrm{m}^{-2}$, whereas in 2009-10, chickpea secondary branches were significantly decreased with an increase in A. tenuifolius density from 20 to 320 when compared with the control. At the highest density level (320 plants $\mathrm{m}^{-2}$ ), only 7.00 chickpea secondary branches were recorded (Table 2). Trend comparisons regarding chickpea secondary branches were significant for linear and cubic responses; however, they were non-significant for quadratic response in 2008-09 and 2009-10 (Table 2). With an increase in $A$. tenuifolius density $\mathrm{m}^{-2}$ from 0 to 320 , a decreased response in chickpea secondary branches was observed in both years due to resource competition and fewer primary branches. Maximum chickpea secondary branches at zero A. tenuifolius $\mathrm{m}^{-2}$ may be due to ample availability of resources and more primary branches in these plots, and the reverse is true with 320 A. tenuifolius $\mathrm{m}^{-2}$. In $A$. tenuifolius free plots, chickpea produced more above ground biomass (primary and secondary branches) as compared to plots where highest $A$. tenuifolius density was maintained from 20 to $320 \mathrm{~m}^{-2}$. Similar results were reported by Singh \& Tewari (1992), who concluded that more light was intercepted, which produced a good canopy in weed free plots in pigeon pea. 
Table 2 showed evidence that varying A. tenuifolius densities $\mathrm{m}^{-2}$ significantly affected chickpea pods per plant. The highest A. tenuifolius density level (320 plants $\mathrm{m}^{-2}$ ) resulted in the lowest chickpea pods per plant which were 30.00 and 33.00 in 2008-09 and 2009-10, respectively, and chickpea pods were increased with a decrease in A. tenuifolius density $\mathrm{m}^{-2}$. Asphodelus tenuifolius free plots resulted in maximum chickpea pods per plant (63.25 and 66.00) in 2008-09 and 2009-10 (Table 2). In trend comparisons, linear and cubic responses were significant in both years. However, quadratic response for chickpea pods per plant was significant in 2008-09 and non-significant in 2009-10 (Table 2). Our findings showed that an increase in A. tenuifolius densities (from 0 to 320 plants $\mathrm{m}^{-2}$ ) resulted in decreased chickpea pods per plant (from 66.00 to 30.00). Our findings are consistent with those of (Aslam et al., 2007). They reported the highest chickpea pods per plant in weed free plots. Khan et al. (2005) revealed that Silybum marianum densities above three plants $\mathrm{m}^{-2}$ resulted in reduction in yield parameters of wheat. Similarly, Khan et al. (2007) reported that 30 plants $\mathrm{m}^{-2}$ of Avena fatua significantly decreased wheat yield and yield components.

Effect of A. tenuifolius densities on chickpea seeds per pod is shown in Table 2. Minimum chickpea seeds per pod (1.50) were recorded at $A$. tenuifolius density level of 80 , 160 or 320 plants $\mathrm{m}^{-2}$ in both years (Table 2). Asphodelus tenuifolius free plots resulted in the highest (2.25) chickpea seeds per pod which was at par with those of 20 and 40 A. tenuifolius plants $\mathrm{m}^{-2}$. Among trend comparisons, linear response was significant and quadratic and cubic responses were nonsignificant for chickpea seeds per pod in both years (Table 2). Our findings concluded that with an increase in A. tenuifolius density $\mathrm{m}^{-2}$ (from 0 to 320), a significant decrease was recorded in chickpea seeds per pod. This decrease in seeds per pod was due to an increase in competition for nutrients and moisture with an increase in A. tenuifolius $\mathrm{m}^{-2}$, as $A$. tenuifolius population shared the available resources, which ultimately resulted in less photosynthate production and transfer towards pods to produce more seeds per pod.
Similar to our findings, Aslam et al. (2007) found a higher number of seeds in chickpea in weed free plots.

Table 2 showed the effect of varying A. tenuifolius densities $\mathrm{m}^{-2}$ on 100 -seed weight of chickpea. Asphodelus tenuifolius free plots resulted in maximum 100-seed weight of chickpea which was at par with 100-seed weight of chickpea from $A$. tenuifolius density of $20 \mathrm{~m}^{-2}$ up to $80 \mathrm{~m}^{-2}$ in both years (Table 2). The tallest $A$. tenuifolius plants $\left(320 \mathrm{~m}^{-2}\right)$ resulted in the lowest 100-seed weight of chickpea (19.89 and $19.70 \mathrm{~g}$ in 2008-09 and 2009-10, respectively), and this was statistically similar where 160 A. tenuifolius plants $\mathrm{m}^{-2}$ were maintained. Linear response of chickpea for 100-seed weight was significant, and quadratic and cubic responses were non-significant in both years (Table 2). Our findings pertaining to chickpea 100-seed weight showed that A. tenuifolius at the highest densities resulted in the lowest 100-seed weight of chickpea. However, a density level up to 80 did not reduce 100-seed weight of chickpea compared with the control (A. tenuifolius free plots). Thus, the observed decrease in 100-seed weight of chickpea with the increase in A. tenuifolius densities were most probably due to limited availability of light, moisture, space and nutrient in highly infested $A$. tenuifolius plots, and this resulted in the lowest chickpea seed weight gain. Our findings are in accordance with the reports of Aslam et al. (2007), who recorded maximum chickpea 100-seed weight in weed free plots and the lowest seed weight in plots highly infested with weeds. Similar to our findings, Oad et al. (2007) revealed that with increasing weed densities, 1000-seed weight was decreased in wheat. Similarly, Silva et al. (2008) observed the lowest 1000seed weight of soybean in plots highly infested with weeds.

Varying the density of $A$. tenuifolius significantly affected chickpea seed yield in both years (Table 2). Maximum seed yield of chickpea was achieved in A. tenuifolius free plots in 2008-09 (2467 $\left.\mathrm{kg} \mathrm{ha}^{-1}\right)$ and 2009-10 $\left(2579 \mathrm{~kg} \mathrm{ha}^{-1}\right)$. An increase in A. tenuifolius density $\mathrm{m}^{-2}$ progressively reduced chickpea seed yield. Yield loss started in plots where 20 plants $\mathrm{m}^{-2}$ were maintained (Table 2). Minimum seed yield was 1118 and 
$1068 \mathrm{~kg} \mathrm{ha}^{-1}$ in 2008-09 and 2009-10, respectively (Table 2). The highest (320) A. tenuifolius density $\mathrm{m}^{-2}$ resulted in the highest chickpea seed yield reduction, which was 1349 and $1511 \mathrm{~kg} \mathrm{ha}^{-1}$ (Table 2) with a percent yield reduction of 54.62 and $58.55 \%$ over A. tenuifolius free plots in both years, respectively. Trend comparisons for chickpea seed yield are given in Table 2, which showed that chickpea yield was significantly different from linear, quadratic and cubic response in both years.

Chickpea seed yield is governed by its yield parameters (number of pods, seeds per pod and 100-seed weight). With increasing A. tenuifolius densities $\mathrm{m}^{-2}$, chickpea yield parameters like pods per plant, seeds per pod and 100-seed weight decreased gradually. Above trend in crop yield reduction with anincrease in weed densities $\mathrm{m}^{-2}$ is reported by many researchers in many field crops. (Mishra et al., 2006) revealed linear yield reduction in chickpea and lentil with an increase in $A$. tenuifolius density up to 800 plants $\mathrm{m}^{-2}$. Similarly, Whish et al. (2002) observed that with increasing weed density, chickpea yield losses were also increased. Yield reduction was high (50\%) even with lower weed densities $\left(<10\right.$ weed plants $\left.\mathrm{m}^{-2}\right)$ and yield losses were increased as row spacing became wider. Our results are further supported by Zimdal et al. (2004), who recorded low yield at higher weed densities. They further reported that yield can never drop to zero with weed infestation. Similarly, previous work showed that yield of other leguminous crops (cowpea and soybean) were significantly reduced with increasing E. heterophylla density (Carvalho et al., 2010). Cowpea growth, yield and yield components also reduced with increasing density of $E$. heterophylla (Olorunmaiye \& Ogunfolaji, 2002). An increase in E. geniculata density from 10 to 120 plants $\mathrm{m}^{-2}$ reduced the seed yield of soybean by $12-30 \%$ and chickpea by $18-53 \%$ in soybean-chickpea cropping system, indicating that at the same density, chickpea was more susceptible to $E$. geniculate than soybean (Mishra \& Singh, 2003; Mohammadi et al., 2005).

\section{Estimation of chickpea yield and yield losses}

A model of density-yield (Cousens, 1985) was used to characterize chickpea yield across A. tenuifolius density. The models estimated that the yields of weed free chickpea $\left(\mathrm{Y}_{\mathrm{wf}}\right)$ were $2458 \mathrm{~kg} \mathrm{ha}^{-1}(95 \%$ CI $[2376,2541])$ and $2563 \mathrm{~kg} \mathrm{ha}^{-1}(95 \%$ CI [2484, 2641]) in 2007-08 and 2008-09, respectively. The estimated percentage yield loss per unit of weed density (i) was 1.88 (95\% CI [1.40, 2.35]) in 2008-10 and 2.13 (95\% CI [1.67, 2.59]) in 2008-10. In contrast, the asymptotic values of the maximum yield loss of chickpea (A) were 56.87 (95\% CI [52.97, 60.76]) and 60.68 (95\% CI [57.20, 64.15]) kg ha-1 in 2007-08 and 2008-09, respectively (Table 3). In 2008-09, maximum chickpea yield losses with one unit of A. tenuifolius and its infinite densities $\mathrm{m}^{-2}$ were 2.18 and $60.73 \%$, respectively. In 2009-10, maximum chickpea yield losses with one unit of $A$. tenuifolius and its infinite densities $\mathrm{m}^{-2}$ were 1.29 and $56.89 \%$, respectively (Table 3). Similarly, Coelho et al. (2009) found that the presence of Ageratum conyzoides, Digitaria nuda, Eleusine indica and Lepidium virginium caused $94 \%$ yield reduction of carrot. The chickpea yield loss estimation

Table 3 - Model estimate of chickpea yield (kg ha-1) and yield losses (\%) in 2008-09 and 2009-10

\begin{tabular}{|c|c|c|c|c|c|c|c|c|c|}
\hline \multirow{2}{*}{\multicolumn{2}{|c|}{ Parameter }} & \multicolumn{2}{|c|}{ Estimate } & \multicolumn{2}{|c|}{ Std. Error } & \multicolumn{2}{|c|}{$95 \% \mathrm{LCI}$} & \multicolumn{2}{|c|}{$95 \% \mathrm{UCI}$} \\
\hline & & 2008-09 & 2009-10 & 2008-09 & 2009-10 & 2008-09 & 2009-10 & 2008-09 & 2009-10 \\
\hline \multirow{3}{*}{$\begin{array}{l}\text { Chickpea } \\
\text { yield }\end{array}$} & $\mathrm{Y}_{\mathrm{wf}}$ & 2458 & 2563 & 42.00 & 40.23 & 2376 & 2484 & 2541 & 2641 \\
\hline & $\mathrm{i}$ & 1.88 & 2.13 & 0.24 & 0.23 & 1.40 & 1.67 & 2.35 & 2.59 \\
\hline & A & 56.87 & 60.68 & 1.99 & 1.77 & 52.97 & 57.20 & 60.76 & 64.15 \\
\hline \multirow{2}{*}{ Yield loss } & $\mathrm{i}$ & 2.18 & 1.90 & 0.172 & 0.197 & 1.84 & 1.51 & 2.52 & 2.29 \\
\hline & A & 60.73 & 56.89 & 1.54 & 1.97 & 57.71 & 53.02 & 63.75 & 60.76 \\
\hline
\end{tabular}

$\mathrm{Y}_{\mathrm{wf}}=$ yield of weed free plot, $\mathrm{i}=$ chickpea yield loss per unit of $A$. tenuifolius, $\mathrm{A}=$ chickpea yield loss at infinite A. tenuifolius density, $\mathrm{LCI}=$ lower confidence interval and UCI $=$ upper confidence interval. 
model showed that maximum yield losses of chickpea occurred with infinite $A$. tenuifolius densities in both years.

An increase in A. tenuifolius density $\mathrm{m}^{-2}$ progressively reduced chickpea seed yield. The model estimate showed that $A$. tenuifolius density at infinity may cause $56-60 \%$ chickpea yield losses. Measures should be taken to control A. tenuifolius in chickpea field at 20 plants $\mathrm{m}^{-2}$.

\section{ACKNOWLEDGEMENTS}

We are grateful to the Higher Education Commission, Pakistan, for providing financial support under the Indigenous Ph.D. fellowship program.

\section{LITERATURE CITED}

ABBAS, R. N. et al. Simulating the effect of Emex australis densities and sowing dates on agronomic traits of wheat. Pak. J. Agric. Sci., v. 47, n. 2, p. 104-110, 2010.

PAKISTAN. Ministry of Food and Agriculture. Agriculture statistics of Pakistan. (Planning unit). Islamabad: 2010/ 2011. 21 p.

ASLAM, M. et al. Effect of sowing methods and weed control techniques on yield and yield components of chickpea (Cicer arietinum L.). Pak. J. Weed Sci. Res., v. 13, n. 1-2, p. 49-61, 2007.

AZIZ, A. A.; TANVEER, A. A.; YASIN, M. Density dependent interactions between Cleavers (Galium aparine) and wheat (Triticum aestivum) planted at different times. Pak. J. Agri. Sci., v. 46, n. 4, p. 258-265, 2008.

CARVALHO, L. B.; BIANCO, S.; GUZZO, C. D. Inteference of Euphorbia heterophylla in the growth and macronutirent accumulation of soybean. Planta Daninha, v. 28, n. 1, p. 33-39, 2010.

COELHO, M.; BIANCO, S.; CARVALHO, L. B. Weed interference on carrot crop (Daucus carrota). Planta Daninha, v. 27, p. 913-920, 2009. (Número Especial).

COUSENS, R. A simple model relating yield loss to weed density. Ann. Appl. Biol., v. 107, n. 2. p. 239-252. 1985.

DEINES, S.R.; DILLE, J. A.; BLINKA,E.L.; REGHER, D. L.; STAGGENBORG, S. A. Common sunflower (Helianthus annuus) and shattercane (Sorghum bicolor) interference in corn. Weed Sci., v. 52, n. 6, p. 976-983, 2004.
FAST, B. J.; MEDLIN. C, R.; MURRAY, D. S. Five coolseason annual grass weeds reduce hard red winter wheat grain yield and price. Weed Technol., v. 23, n. 2, p. 206-213, 2009.

FLECK, N. G.; RIZZARDI. M. A.; AGOSTINETTO, D. Threshold level as a criteria for arrowleaf sida control decision in soybeans. Planta Daninha, v. 20, n. 3, p. 421-429, 2002.

HOLM, R. et al. World weeds, natural histories and distribution. New York: John Wiley and Sons, 1977.

KHAN, I. J. et al. Effect of wild oats (Avena fatua) densities and proportions on yield and yield components of wheat. Agric. Biol. Sci., v.1, n. 1, p. 26-31, 2007.

KHAN, M. A.; MARWAT, K. B.; HASSAN, G. Grain yield of wheat at various seed rates under Holy thistle (Silybum marianum) densities. Herbologia, v. 6, n. 3, p. 13-17, 2005.

KHAN, M. A.; MARWAT, K. B. Impact of crop and weed densities on competition between wheat and Silybum marianum Gaertn. Pak. J. Bot., v. 38, n. 4, p. 1205-1215, 2006.

KNEZEVIC, S. Z. et al. Critical period for weed control. The concept and data analysis. Weed Sci., v. 50, p. 773-786, 2002.

MISHRA, J. S.; SINGH, V. P. Interference of Euphorbia geniculata in soybean-chickpea cropping system. Indian J. Weed Sci., v. 35, n. 3/4, p. 225-227, 2003.

MISHRA, J. S.; SINGH, V. P.; YADURAJU, N. T. Wild onion (Asphodelus tenuifolius Cav.) interference in lentil and chickpea crops and its management through competitive cropping. Weed Biol. Manag., v. 6, n. 3, p. 151-156, 2006.

MOHAMMADI, G. et al. Critical period of weed interference in chickpea. Weed Res., v. 45, n. 1, p. 57-63, 2005.

NASIR, Z. A.; SULTAN, S. Survey of weeds in mustard fields of district Chakwal, Pakistan. Pak. J. Biol. Sci., v. 7, n. 2, p. 279-286, 2004.

OAD, F.; SIDDIQUI, M.; BURIRO, U. Growth and yield losses in wheat due to different weed densities. Asian J. Plant Sci., v. 6, n. 1, p. 6173-6176, 2007.

OLORUNMAIYE, K. S.; OGUNFOLAJI, R. T. Effect of density and duration of Euphorbia heteropylla (L.) on the performance of cowpea (Vigna unguiculata) (Walp). NISEB J., v. 2, n. 1, p. 17-22, 2012.

ONOFRI, A.; TEI, F. Competitive ability and threshold levels of three broad leaf weed species in sunflower. Weed Res., v. 34, n. 6, p. 471-479, 2006. 
PORTUGAL, J. M.; VIDAL, R. A. Economic levels of weed injury on crops: Concepts, definitions and calculation models. Planta Daninha, v. 27, n. 4, p. 869-877, 2009.

RIZZARDI, M. A. et al. Interference of populations of Euphorbia heterophylla and Ipomoea ramosissima isolated or in mixture in soybean crop. Planta Daninha, v. 22, n. 1, p. 29-34, 2004.

SESTER, M. et al. Crop and density effects on weed beet growth and reproduction. Weed Res., v. 44, n. 1, p. 50-59, 2004.

SILVA, A. F. et al. Effect of weed densities and control periods on soybean yield components. Planta Daninha, v. 26, n. 1, p. 65-71, 2008.

SINGH, K. K.; TEWARI, A. N. Weed management in intercropped pigeonpea. Indian J. Weed Sci., v. 24, n. 3-4, p. 21-25, 1992.
STEEL, R. G. D. et al. Principles and Procedures of Statistics. Multiple comparisons. 3.ed. McGraw Hill Book Co., New York, USA. p. 178-198, 1997.

TANVEER, A. et al. Effect of different levels of weed management on weed growth and grain yield of gram (Cicer arietinum L.). Pak. J. Sci., v. 50, n. 3-4, p. 60-62, 1998.

TIWARI, A. N. et al. Crop-weed competition studies in chickpea having Asphodelus tenuifolius dominated weed community under rain fed condition. Indian J. Weed Sci. v. 33, n. 3-4, p. 198-199, 2001.

WHISH, J. P. M. et al. The development of a wild oat simulation model for APSIM. Victoria Park: Plant Protection Society of Western Australia, 2002.

ZIMDAHL, R .L. Weed crop competition. Blakwell publication. Canada, 2004. 22 p. 